\begin{tabular}{|c|c|c|c|c|}
\hline & \multirow[t]{2}{*}{ Interval type } & \multicolumn{3}{|l|}{$\begin{array}{l}\text { Non-interval } \\
\text { type }\end{array}$} \\
\hline & & type A & type B & type C \\
\hline Examples & $\begin{array}{l}\text { Detected prior to } \\
\text { recommended } \\
\text { screening/ } \\
\text { surveillance } \\
\text { interval } \\
\text { Patient with } 2 \\
\text { small adenomas } \\
\text { is advised to } \\
\text { return for } \\
\text { surveillance in } \\
5 \text { years; } 4 \text { years } \\
\text { later develops } \\
\text { anaemia; } \\
\text { colonoscopy } \\
\text { reveals CRC }\end{array}$ & $\begin{array}{l}\text { Detected at } \\
\text { recommended } \\
\text { screening/ } \\
\text { surveillance } \\
\text { interval } \\
\text { Patient with a } \\
15 \mathrm{~mm} \text { adenoma } \\
\text { is advised to } \\
\text { return for } \\
\text { surveillance in } \\
3 \text { years; at } \\
3 \text { years, a CRC is } \\
\text { found }\end{array}$ & $\begin{array}{l}\text { Detected after } \\
\text { recommended } \\
\text { screening/ } \\
\text { surveillance } \\
\text { interval } \\
\text { Patient with } 3 \\
\text { adenomas is } \\
\text { advised to return } \\
\text { for surveillance in } \\
3 \text { years. Patient } \\
\text { misses this, } \\
\text { returns } 4 \text { years } \\
\text { later with CRC }\end{array}$ & $\begin{array}{l}\text { Where no } \\
\text { screening/ } \\
\text { surveillance } \\
\text { interval had been } \\
\text { recommended } \\
\text { Patient } \\
\text { investigated for } \\
\text { change in bowel } \\
\text { habit - } \\
\text { colonoscopy } \\
\text { normal. No } \\
\text { further } \\
\text { investigation } \\
\text { recommended. } \\
5 \text { years later } \\
\text { patient develops } \\
\text { symptoms and a } \\
\text { colonoscopy } \\
\text { reveals CRC }\end{array}$ \\
\hline
\end{tabular}

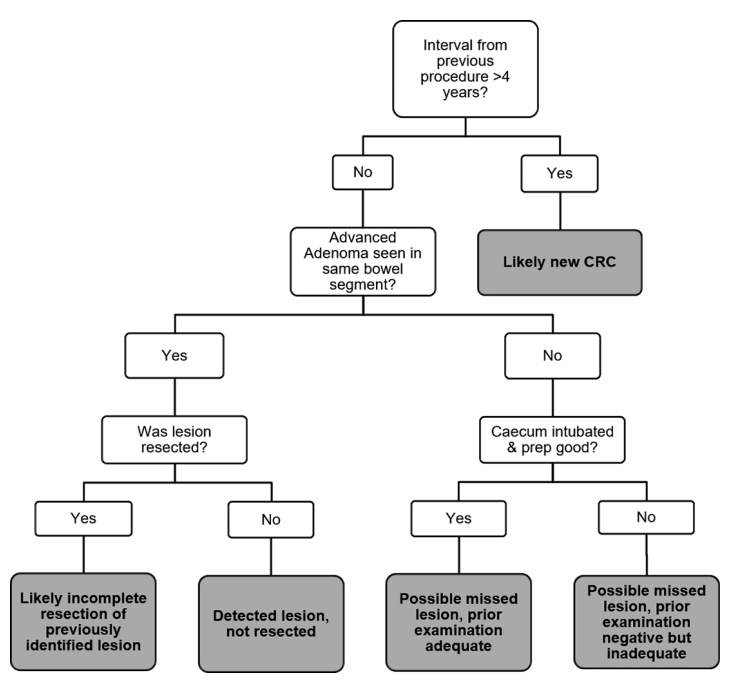

Abstract PTU-031 Figure 1 Proposed algorithm for aetiology attribution of PCCRC cases

Conclusions This is the first consensus aiming to standardise terminology around PCCRC/PICRC, presenting a methodology for analysis of causation of PCCRC/PICRC and defining its potential role as a key quality indicator.

\section{PTU-032 POST-COLONOSCOPY COLORECTAL CANCER RATES IN IBD ARE HIGH AND VARY BY NHS TRUST IN ENGLAND}

${ }^{1}$ Nicholas Burr*, ${ }^{2}$ Roland Valori, ${ }^{1}$ Venkataraman Subramanian, ${ }^{1}$ Mark Hull, ${ }^{3}$ Jon Shelton, ${ }^{3}$ Clare Pearson, ${ }^{1}$ Andy Smith, ${ }^{1}$ Eva Morris, ${ }^{4}$ Matthew Rutter. ${ }^{1}$ University of Leeds; ${ }^{2}$ Gloucestershire Hospitals; ${ }^{3}$ Cancer Research UK; ${ }^{4}$ North Tees University Hospitals NHS Trust

\subsection{6/gutjnl-2018-BSGAbstracts.373}

Introduction Colorectal cancer (CRC) risk is increased in those with inflammatory bowel disease (IBD). Guidelines advocate surveillance colonoscopy for patients with longstanding IBD. Post-colonoscopy colorectal cancer (PCCRC) is a key quality indicator of colonoscopy. There is limited data exploring the rate of PCCRC in those with IBD and potential risk factors associated with IBDrelated PCCRC.

This study explored national and individual hospital rates of IBD-related PCCRC in England since 2006. Further analysis explored potential associations with IBD-related PCCRC in order to inform future quality improvement interventions.

Methods We identified all those who had undergone a colonoscopy between 1/1/2006 and 31/12/2012 and developed a CRC before 31/12/2015 using linked national Hospital Episode Statistics and National Cancer Registration and Analysis Service data. IBD cases were identified by relevant ICD-10 codes. Using international consensus guidelines ${ }^{1,2}$ the rate of PCCRC within 3 years (PCCRC-3 yr) was calculated as the number of false negative colonoscopies (within 6-36 months of $\mathrm{CRC}$ ) divided by the sum of the true positive (within 6 months of CRC) and false negative colonoscopies. The IBDassociated PCCRC-3 yr rate in each NHS hospital trust in England was ranked and trusts were separated into quintiles. Factors associated with IBD-related PCCRC were investigated.

Results Between 2006 and 2012 we identified 7781 PCCRC, $800(10 \%)$ with a diagnosis of IBD. Nationally, the IBDPCCRC-3 yr rate was 35\%, and varied between hospital trusts with those in the lowest quintile having a mean, unadjusted rate of $19 \%(\mathrm{SD} \pm 7 \%$ ) compared to $52 \%(\mathrm{SD} \pm 7 \%)$ in the highest quintile. PCCRC cases were younger at diagnosis (60 years compared to 66 years), were less likely to have diverticular disease (10\% compared to $16 \%)$, and had undergone more previous colonoscopies when compared to detected cases (within 6 months of colonoscopy). There was no significant difference for sex, bowel location, deprivation score, or metachronous tumours.

Conclusion PCCRC-3 yr in those with IBD is high, and accounted for 10\% of all PCCRC-3 yr in England between 2006 and 2012. There is a wide variation in the unadjusted rates between NHS trusts in England that is unlikely to be explained by natural variation. There is an urgent need to investigate avoidable reasons for cancers in those with IBD to optimise surveillance and prevention of CRC in IBD.

\section{PTU-033 COLORECTAL CANCER AND EXPERIENCE IN TESTING FOR LYNCH SYNDROME IN A WEST LONDON HOSPITAL}

Anna Cavazza*, Chandni Radia, Christopher Harlow, Kevin J Monahan. Family History of Bowel Cancer Clinic, Department of Gastroenterology, West Middlesex University Hospital, Chelsea and Westminster Hospital NHS Foundation Trust, London, UK

\subsection{6/gutjnl-2018-BSGAbstracts.374}

Introduction Colorectal cancer (CRC) is diagnosed in over 46000 people in the UK annually, and is the second most common cause of cancer death. NICE guideline DG27 recommends universal testing for Lynch Syndrome (LS) at diagnosis of colorectal cancer, by testing the CRC for mismatch repair (MMR) status, a hallmark of the disease.

Methods We collected data prospectively from November 2016 to December 2017 of consecutively diagnosed CRC 